\title{
The Cross Talk Between ROS And NO In The Viability Decline of Cryopreserved Pollen From Paeonia Lactiflora
}

Ruifen Ren

Beijing Forestry University

Lingling Zhang

Beijing Forestry University

Hao Zhou

Beijing Forestry University

Xueru Jiang

Beijing Forestry University

Yan Liu ( $\nabla$ yanwopaper@yahoo.com )

Beijing Forestry University, Beijing $\rrbracket$ China https://orcid.org/0000-0001-5856-7665

\section{Research Article}

Keywords: Cryopreservation, Pollen, Viability, Reactive oxygen species, Nitric oxide

Posted Date: November 30th, 2021

DOI: https://doi.org/10.21203/rs.3.rs-1091964/v1

License: (c) (1) This work is licensed under a Creative Commons Attribution 4.0 International License. Read Full License 


\section{Abstract}

Reactive oxygen species (ROS) and nitric oxide (NO), two common active molecules, are both involved in changes in viability after liquid nitrogen (LN) storage, but the relationship between these two molecules has not been examined in plant cryopreservation until now. In this study, the pollen of Paeonia lactiflora 'Fen Yu Nu' with significantly decreased viability after cryopreservation was used as the material. We studied the effects of the two regulators on each other and their biosynthesis and scavenging indices to explore the interaction between ROS and NO in pollen cryopreservation and its mechanism. The results showed that the contents of ROS and NO increased significantly with the decrease of pollen viability after cryopreservation, and changes in the ROS and NO content had a significant effect on post-LN pollen viability. The ROS content positively regulated the endogenous NO content and had significant effects on the expression level of NOS-like enzyme regulation gene CSU2 and its activity. Down-regulated NO had a positive effect on the ROS content, and it significantly affected the expression of nicotinamide adenine dinucleotide phosphate (NADPH) oxidase and its regulatory gene $R B O H J$. It also significantly affected catalase (CAT) and substrates related to the ascorbic acid (AsA)-glutathione (GSH) antioxidant cycle system. These results indicate that there was a positive interaction between ROS and NO in pollen cryopreservation. The NOS biosynthesis pathway is one of the ROS-regulated NO pathways, and the NADPH oxidase, CAT and AsA-GSH antioxidant cycle systems are the key sites of regulation of the ROS content by NO.

\section{Key Message}

There was a positive interaction between ROS and NO in the decline of viability of Paeonia lactiflora 'Fen Yu Nu' pollen after cryopreservation.

\section{Introduction}

Pollen carries all of the male genetic information of plants, and its safe and effective preservation has great significance for the conservation of plant germplasm resources. A large number of studies have shown that cryopreservation is one of the key ways to preserve germplasm for a long time (Zhang et al., 1993; Souza et al., 2015; Engelmann, 2004) and it has been successfully applied to the long-term preservation of pollen of many species (Dmura and Akihama, 1980; Mercier, 1995; Li, 2005; Zhang, 2007; Li, 2010; Borghezan et al., 2011; Xu, 2014; Dinato et al., 2018). However, some problems have been found in practical applications. Pollen viability mainly shows three different trends after cryopreservation, and in most cases, it was significantly decreased (Zhang, 2007; Xu et al., 2014; Ren et al., 2019a; Li, 2019). According to previous studies, the decrease in pollen viability after cryopreservation is mainly due to osmotic stress and low-temperature stress during preservation in liquid nitrogen (LN). Other studies have found that reactive oxygen species (ROS) and nitric oxide (NO) may play a key role in this process (Ren et al., 2020b; Ren et al., 2021). 
ROS and NO are signal transduction molecules in plant and animal cells that respond to stress and regulate a variety of physiological phenomena (Wilkins et al., 2011). Studies on plant stress have not only clarified the changes in ROS and NO but also discussed the relationship and the mechanism of interaction between these two factors. In the occurrence of programmed cell death (PCD) of Nicotiana tabacum var. samsun. suspension cells induced by chitosan, a large amount of ROS synthesis was induced along with the production of NO (Zhang et al., 2012). NO production was enhanced by ROS production during the occurrence of PCD in suspension cells of Nicotiana tabacum callus induced by sphingine and dihydrosphingine (Da Silva et al., 2011). The relationship between these two molecules and their possible interaction pathways were further proven by exogenous addition experiments. The study of Esim and Atici (2014) showed that exogenous spraying of NO could improve the activity of antioxidant enzymes and reduce the ROS level of Zea mays under low temperature stress, which plays an important role in improving cold resistance. Xiao's (2014) study found that exogenous NO donor sodium nitroferricyanide (III) dihydrate (SNP) increased the activity of NADPH and NADP ${ }^{+}$, while NO scavenger carboxy-PTIO potassium salt (c-PTIO), NADPH oxidase inhibitor diphenyleneiodonium chloride (DPI) and hydrogen peroxide $\left(\mathrm{H}_{2} \mathrm{O}_{2}\right)$ scavenger dimethylthiourea (DMTU) inhibited the effect induced by the SNP, indicating that interactions between ROS and NO in Cucumis sativus seedlings under cold stress, NADPH and $\mathrm{NADP}^{+}$activity may be the critical factors.

In plant cryopreservation, it has been found that the stress involved in the process of LN preservation has a certain influence on the production of intracellular ROS and NO, and the production of ROS and NO is involved in the changes in viability after LN storage. Zhang (2015), in the cryopreservation of calli from Agapanthus praecox, found that the ROS content significantly increased after preservation with LN, and it had a significant effect on cell activity after cryopreservation by inducing oxidative stress and programmed cell death. In cryopreservation of protocorms of Dendrobium nobile, Jiang (2019a) found that NO was produced during the cryopreservation process and had dual regulatory effects on cell activity after preservation in LN. Other studies on cryopreservation of Dendrobium nobile protocorms showed that there was a certain relationship between ROS and NO (Jiang, 2019b). However, the existing studies on how these two molecules work have not been addressed in plant cryopreservation.

In addition, studies on ROS and NO in pollen cryopreservation are relatively rare, and most of the existing studies only focus on the production of ROS and its effects on viability after preservation in LN. Ren (2020b), in the cryopreservation of Paeonia lactiflora pollen, found that the content of ROS was significantly increased after preservation in $\mathrm{LN}$, and ROS had a significant impact on post-LN viability by mediating the occurrence of PCD. In the cryopreservation of Paeonia lactiflora, NO was also found to be involved in the changes in pollen viability after preservation with LN by regulating PCD (Ren et al., 2021). Thus, in this study, the pollen of Paeonia lactiflora 'Fen Yu Nu' with significantly decreased viability after cryopreservation was used as the materials. We compared and analyzed the changes of ROS and NO contents before and after cryopreservation, and studied their effects on each other and the related synthetases by using their modulators to clarify the relationship between ROS and NO in pollen cryopreservation and their possible pathways of action. 


\section{Materials And Methods}

\section{Pollen collection and cryopreservation}

Pollen of $P$. lactiflora 'Fen Yu Nu' was collected at the International Peony Garden in Luoyang, Henan Province, on April 29, 2019. When the air humidity was appropriate for drying, a bud that was about to open was selected and the anther was gently removed and placed at $4{ }^{\circ} \mathrm{C}$. Then, the anthers were placed at room temperature $\left(23 \pm 2{ }^{\circ} \mathrm{C}\right)$ for $24 \mathrm{~h}$ to completely disperse the pollen. The pollen was collected with an $80 \mathrm{~mm}$ aperture sieve (Ren et al., 2019b).

The collected pollen ( $0.1 \mathrm{~g} /$ package) was divided into tin foil packets, placed in a $2 \mathrm{~mL}$ cryotube, and then directly put into LN for storage. After 3 months of storage, the cryotube (containing the tinfoilwrapped pollen) was rewarmed under running water or thawed at room temperature.

\section{Pollen moisture content and viability determination}

The moisture content of fresh pollen was determined by the $105^{\circ} \mathrm{C}$ constant temperature drying method (Ren et al., 2019b).

Pollen variability was evaluated by the pollen germination rate. The pollen germination rate before and after cryopreservation was detected by the hanging drop culture method. The medium was $10 \%$ sucrose and $0.1 \%$ boric acid. The germination conditions were $25^{\circ} \mathrm{C}$ for $4 \mathrm{~h}$ without light. A pollen tube length greater than twice the pollen grain diameter was the criterion for pollen germination. Four replicates were performed for every treatment, and three fields were randomly selected for each replicate (at least 300 grains). The germination number was counted with a 20X eyepiece (Leica DM-500), and the mean value of the results was taken (Ren et al., 2019b).

\section{Pollen NO content determination}

NO content was determined by diaminofluorescein-FM diacetate (DAF-FM DA) fluorescence staining. Pollen $(0.01 \mathrm{~g})$ was added to $200 \mu \mathrm{L}$ DAF-FM DA $(100 \mu \mathrm{mol} / \mathrm{L})$ fluorescent probe (Biyuntian Biotechnology Co., Ltd., S0019) in the dark and thoroughly mixed. Then, the cells were incubated at $37^{\circ} \mathrm{C}$ for 30 min without light and centrifuged at $2000 \mathrm{rpm}$ for $20 \mathrm{~s}$, and the fluorescent dye was discarded. The fluorescently loaded pollen was washed twice with $500 \mu \mathrm{LBS}(\mathrm{pH}=7.4)$, and $1 \mathrm{~mL} \mathrm{PBS}(\mathrm{pH}=7.4)$ was used to resuspend the precipitated pollen. A flow cytometer (FACSCalibur, Becton-Dickinson, Franklin Lakes, NJ, USA) was used to measure the fluorescence values in the FITC channels. The actual fluorescence measurement value was the relative content of NO, and each treatment was repeated 3 times.

\section{Pollen ROS content determination}

ROS content was determined by fluorescence staining with 2',7'-2,7-dichlorodihydrofluorescein diacetate (DCFH-DA) (Xu, 2014). A $0.01 \mathrm{~g}$ sample of pollen was added to $200 \mu \mathrm{L}$ DCFH-DA $(100 \mu \mathrm{mol} / \mathrm{L})$ 
fluorescent probe (Sigma Chemical Co., St Louis, MO, USA, D6883-50MG) without light and thoroughly mixed. The pollen was incubated at $37^{\circ} \mathrm{C}$ for $30 \mathrm{~min}$ in the dark, centrifuged at $2000 \mathrm{rpm}$ for $20 \mathrm{~s}$, and the dye solution was discarded. The pollen was washed twice with $500 \mu \mathrm{LBS}(\mathrm{pH}=7.4)$, and then it was resuspended in $1 \mathrm{~mL}$ PBS $(\mathrm{pH}=7.4)$. The fluorescence was measured in the FITC channel by flow cytometry (FACSCalibur, Becton-Dickinson, Franklin Lakes, NJ, USA). The actual fluorescence measurement value was taken as the NO content, and every treatment was repeated 3 times.

\section{Pollen NOS-like activity determination}

Nitric oxide-like synthase (NOS-like) activity was determined by a kit (S0025) provided by Biyuntian Biotechnology Co., Ltd. Pollen $(0.01 \mathrm{~g})$ was added to $100 \mu \mathrm{L}$ NOS detection buffer, $79.6 \mu \mathrm{L}$ Milli-Q water, $10 \mu \mathrm{L}$ arginine solution, $10 \mu \mathrm{L}$ NADPH solution $(0.1 \mathrm{mM})$ and $0.4 \mu \mathrm{L}$ DAF-FM DA solution $(5 \mathrm{mM})$, and the mixture was incubated at $37^{\circ} \mathrm{C}$ for 30 min without light. Flow cytometry (FACSCalibur, Becton-Dickinson, Franklin Lakes, NJ, USA) was used to detect the fluorescence value in the FITC channel, taking the actual fluorescence measurement value as the NOS-like activity, and each treatment was repeated 3 times.

\section{Pollen NDAPH oxidase activity determination}

Nicotinamide adenine dinucleotide phosphate (NDAPH) enzyme activity was determined according to the $\mathrm{NADP}+/ \mathrm{NADPH}$ detection kit (S0179) provided by Biyuntian Biotechnology Co., Ltd. The pollen $(0.01 \mathrm{~g})$ was homogenized in an ice bath with $400 \mu \mathrm{L} \mathrm{NADP}^{+} / \mathrm{NADPH}$ extraction buffer and centrifuged at 12,000 rpm at $4{ }^{\circ} \mathrm{C}$ for $10 \mathrm{~min}$. Then, $200 \mu \mathrm{L}$ glucose-6-phosphate dehydrogenase (G6PDH) working solution was added to $100 \mu \mathrm{L}$ extraction solution and incubated at $37^{\circ} \mathrm{C}$ for 10 min without light. Then, $10 \mu \mathrm{L}$ chromogen solution was added, mixed well and incubated for $60 \mathrm{~min}$ at $37^{\circ} \mathrm{C}$ without light. The absorbance was measured at $450 \mathrm{~nm}$ with an ultraviolet spectrophotometer. Each treatment was repeated three times, and the average of the results was taken.

\section{Pollen antioxidants determination}

Superoxide dismutase (SOD) activity was determined by the nitrogen blue tetrazole (NBT) reduction method (Li et al., 2000). Pollen $(0.05 \mathrm{~g})$ was homogenized with $1 \mathrm{~mL}$ of $0.05 \mathrm{~mol} / \mathrm{L}$ phosphoric acid buffer in an ice bath and centrifuged at $10,000 \mathrm{rpm}$ at $4{ }^{\circ} \mathrm{C}$ for $15 \mathrm{~min}$. Then, $1.5 \mathrm{~mL}$ phosphoric acid buffer ( $0.05 \mathrm{~mol} / \mathrm{L}), 1.5 \mathrm{~mL}$ methionine solution $(130 \mathrm{mmol} / \mathrm{L}), 300 \mu \mathrm{L} \mathrm{NBT}$ solution $(750 \mathrm{~mol} / \mathrm{L}), 300 \mu \mathrm{L}$ EDTA- $\mathrm{Na}_{2}(100 \mathrm{~mol} / \mathrm{L})$ and $300 \mu \mathrm{L}$ riboflavin solution $(20 \mu \mathrm{mol} / \mathrm{L})$ were added to $300 \mu \mathrm{L}$ extraction solution without light. The mixture was subjected to $4000 \mathrm{~lx}$ ray reaction for $15 \mathrm{~min}$, and the reaction was terminated in darkness. The absorbance value was determined by spectrophotometry at a wavelength of $560 \mathrm{~nm}$. Every treatment was repeated three times, and the average of the results was taken.

Catalase (CAT) activity was measured according to Prochakova's (2001) method with slight modifications. Pollen $(0.05 \mathrm{~g})$ was homogenized with $1 \mathrm{~mL} 0.05 \mathrm{~mol} / \mathrm{L}$ phosphate buffer in an ice bath and centrifuged at $10,000 \mathrm{rpm}$ at $4{ }^{\circ} \mathrm{C}$ for $15 \mathrm{~min}$. Then, $1.5 \mathrm{~mL}$ phosphoric acid buffer $(\mathrm{pH}=7.0)$ and 1.0 $\mathrm{mL}$ distilled water were added to $200 \mu \mathrm{L}$ of the extraction solution and $300 \mu \mathrm{L}$ hydrogen peroxide solution 
$(0.1 \mathrm{~mol} / \mathrm{L})$ was added to initiate the reaction. The absorbance value was measured at a wavelength of $240 \mathrm{~nm}$ by a spectrophotometer. Each treatment was repeated three times, and the mean value was taken.

Glutathione reductase (GR) activity was determined according to the glutathione reductase assay kit (S0055) provided by Biyuntian Biotechnology Co., Ltd. with slight modifications. Phosphate buffer solution ( $1 \mathrm{ml}, 0.01 \mathrm{~mol} / \mathrm{L}$ ) was added to $0.03 \mathrm{~g}$ pollen and it was ground to a homogenate in an ice bath and then centrifuged at $10,000 \mathrm{rpm}$ at $4{ }^{\circ} \mathrm{C}$ for $15 \mathrm{~min}$. The supernatant was collected for the determination of GR activity, and every treatment was repeated three times.

Ascorbic acid reductase (APX) activity was determined using the method of Nakano and Asada (1981) with slight modifications. APX enzyme extraction reagent $(1 \mathrm{ml}, 50 \mathrm{mmol} / \mathrm{L} \mathrm{PBS}+2 \mathrm{mmol} / \mathrm{L}$ AsA+5 $\mathrm{mmol} / \mathrm{L} \mathrm{EDTA}$ ) was added to $0.03 \mathrm{~g}$ pollen, and it was homogenized in an ice bath and centrifuged at $10,000 \mathrm{rpm}$ at $4^{\circ} \mathrm{C}$ for $20 \mathrm{~min}$. To $50 \mu \mathrm{L}$ of the extract, we added $2 \mathrm{~mL}$ PBS $(50 \mathrm{mmol} / \mathrm{L}, \mathrm{pH}=7.0), 500 \mu \mathrm{L}$ AsA solution ( $5 \mathrm{mmol} / \mathrm{L})$ and $500 \mu \mathrm{L}$ EDTA- $\mathrm{Na}_{2}(1 \mathrm{mmol} / \mathrm{L})$, then added $50 \mu \mathrm{L} \mathrm{H}_{2} \mathrm{O}_{2}(30 \%)$ to initiate the reaction. The absorbance was measured at $290 \mathrm{~nm}$ with a spectrophotometer. Each treatment was repeated three times, and the results were averaged.

Ascorbic acid (AsA) content was determined by Kampfenkel's (1995) method with some modifications. The pollen $(0.03 \mathrm{~g})$ with $1.5 \mathrm{~mL}$ trichloroacetic acid $(10 \%)$ was homogenized in an ice bath and centrifuged at $10,000 \mathrm{rpm}$ at $4^{\circ} \mathrm{C}$ for $10 \mathrm{~min}$. Then, $200 \mu \mathrm{L}$ sodium dihydrogen phosphate solution (150 $\mathrm{mmol} / \mathrm{L}$ ) and $200 \mu \mathrm{L} \mathrm{ddH_{2 }} \mathrm{O}$ were added to $200 \mu \mathrm{L}$ of the supernatant extract, and it was mixed for at least $30 \mathrm{~s}$. Then, we added $10 \%$ trichloroacetic acid solution, $44 \%$ phosphoric acid solution and $4 \% 2,2-$ dipyridine solution in turn, $400 \mu \mathrm{L}$ each. The reaction was mixed and initiated by adding $200 \mu \mathrm{L} \mathrm{FeCl}$ (3\%) and then incubated at $37^{\circ} \mathrm{C}$ for $1 \mathrm{~h}$. The absorbance was measured at $525 \mathrm{~nm}$ by a spectrophotometer, each treatment was repeated 3 times, and the mean value of the results was taken.

The glutathione (GSH) content was determined by the 2-nitrobenzoic acid (DTNB) reduction method (Griffith, 1980). First, $1.5 \mathrm{~mL}$ trichloroacetic acid (10\%) was added to $0.03 \mathrm{~g}$ pollen, it was homogenized in

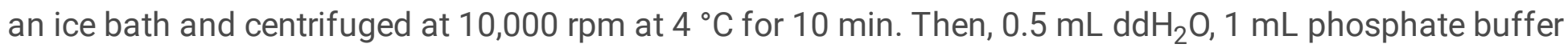
$(1 \mathrm{mmol} / \mathrm{L}, \mathrm{pH}=7.7)$ and $0.5 \mathrm{~mL}$ DTNB $(4 \mathrm{mmol} / \mathrm{L})$ were added to $0.5 \mathrm{~mL}$ of the supernatant extract, mixed well and reacted for $10 \mathrm{~min}$ at $25^{\circ} \mathrm{C}$. The absorbance was measured at $412 \mathrm{~nm}$ by a spectrophotometer. Each treatment was repeated three times, and the average of the results was taken.

\section{qRT-PCR analysis of pollen ROS and NO related genes}

Pollen total ribonucleic acid (RNA) extracted by the Plant RNA Rapid Extraction Kit (RN38-EasySpin Plus) provided by Beijing Aidlab Biotechnologies Co., Ltd. cDNA was synthesized by Rever Tra Ace ${ }^{\circledR}$ qPCR RT Master Mix with gDNA Remover kit (TOYOBO, Osaka, Japan). The primers were designed by IDT online software (https://sg.idtdna.com/Primerquest/Home/Index) and synthesized by Beijing Ruiboxingke Biological Technology Co., Ltd. (Table S1 and Table S2). 
According to the instructions of the SYBR Premix EX Taq (Takara, Otsu, Japan) on the MiniOpticon ${ }^{\mathrm{TM}}$ real- $^{-}$ time PCR detection system (Bio-Rad ${ }^{\circledR}$, Hercules, CA), real-time quantitative PCR was performed. The amplification protocols for qRT-PCR included an initial denaturing step $\left(95^{\circ} \mathrm{C}\right.$ for $\left.30 \mathrm{~s}\right)$, followed by 40 cycles of $95^{\circ} \mathrm{C}$ for $10 \mathrm{~s}, \mathrm{Tm}\left({ }^{\circ} \mathrm{C}\right.$ ) for $15 \mathrm{~s}$, and $72{ }^{\circ} \mathrm{C}$ for $15 \mathrm{~s} ; 65^{\circ} \mathrm{C}$ for $5 \mathrm{~s}$ and $95^{\circ} \mathrm{C}$ for $5 \mathrm{~s}$ (Wan et al., 2019). The reaction system was $20 \mu \mathrm{L}$, including $1 \mu \mathrm{L} \mathrm{cDNA}, 2 \mu \mathrm{L}$ forward primer $(10 \mu \mathrm{mol} / \mathrm{L}), 2 \mu \mathrm{L}$ reverse primer $(10 \mu \mathrm{mol} / \mathrm{L}), 5 \mu \mathrm{L} \mathrm{ddH_{2 }}$, and $10 \mu \mathrm{LSYBR}^{\circledR}$ Premix Ex Taq II (Tli RNase Plus) (2X). The expression level of the target gene was calculated by the $2^{-\Delta \Delta C t}$ method, and each treatment was repeated 3 times.

\section{Addition of ROS and NO exogenous regulator}

In pollen without running water treatment after preservation in LN, $0.8 \mathrm{mmol} / \mathrm{L}$ NO carrier SNP (2287105G, Sigma Chemical Co., St. Louis, MO, USA), 0.8 mmol/L NO scavenger c-PTIO (C221-10MG, Sigma Chemical Co., St. Louis, MO, USA), 200 mmol/L ROS scavenger AsA (A7506-25G, Sigma Chemical Co., St. Louis, MO, USA) or 0.16 mmol/L ROS scavenger GSH (G6013-5G, Sigma Chemical Co., St. Louis, MO, USA) solution was added at a ratio of 1:100 $(w / v)$ and thoroughly mixed. After incubation for $10 \mathrm{~min}$ in the dark at $37^{\circ} \mathrm{C}$, the pollen incubated with the regulator was washed three times with phosphate buffer (PBS, $\mathrm{pH}=7.4$ ) at $0.01 \mathrm{~mol} / \mathrm{L}$. After centrifugation at $2000 \mathrm{rpm}$ for $30 \mathrm{~s}$, the precipitated pollen was used for the determination of various indices, and three repeats were set for each treatment.

\section{Statistical analysis}

Flow cytometry data were processed and analyzed with FlowJO software. SPSS 17.0 (Version 17.0 SPSS Inc., Chicago, IL, USA) was used for one-way ANOVA and correlation analysis. Microsoft Excel 2013 software (Microsoft Corp., Richmond, CA, USA) was used to draw the charts and tables.

\section{Results}

\section{Changes in pollen viability before and after cryopreservation}

The moisture content of the pollen of Paeonia lactiflora 'Fen $\mathrm{Yu} \mathrm{Nu}^{\prime}$ was $8.10 \%$, and the fresh pollen viability was $22.73 \%$. However, cryopreservation significantly reduced the pollen viability (Table 1 ); in particular, the viability of pollen thawed to room temperature after preservation with LN was significantly lower than that of fresh pollen, decreased by $6.31 \%$, while the viability of pollen thawed by running water after $\mathrm{LN}$ storage was only reduced by $1.93 \%$ compared with that of fresh pollen. 
Table 1

Moisture content and germination percentage of $P$. lactiflora pollen

\begin{tabular}{|c|c|c|c|c|}
\hline \multirow[t]{2}{*}{ Cultivar } & \multirow[t]{2}{*}{ Moisture content / \% } & \multicolumn{3}{|c|}{ Germination percentage / \% } \\
\hline & & Fresh & LN & Thaw \\
\hline P. lactiflora 'Fen Yu Nu' & $8.10 \pm 0.59$ & $22.73 \pm 1.64 a$ & $16.42 \pm 0.82 b$ & $20.80 \pm 2.27 a$ \\
\hline
\end{tabular}

\section{Changes in ROS and NO contents in pollen before and after cryopreservation}

Cryopreservation resulted in significant changes in the ROS and NO contents of Paeonia lactiflora 'Fen Yu $\mathrm{Nu}$ ' pollen $(\mathrm{P}<0.05)$. The ROS content of pollen was significantly higher than that of fresh pollen after $L N$ storage with and without running water thawing treatment, increased by $42.85 \%$ and $47.38 \%$, respectively (Fig. 1- A, B, C, D).

The NO content of Paeonia lactiflora 'Fen Yu Nu' pollen with and without running water treatment after LN preservation was significantly higher than that of fresh pollen $(P<0.05), 92.71 \%$ and $94.14 \%$, respectively (Fig. 1-E, F, G, H).

\section{Correlation analysis among pollen viability, ROS and NO content before and after cryopreservation}

Before and after cryopreservation, the pollen viability was negatively correlated with the contents of ROS and NO $(P<0.05)$. In addition, ROS content was positively correlated with NO content $(P<0.01)($ Table 2$)$.

Table 2

Correlation analysis among pollen viability, ROS content and NO content before and after cryopreservation

\begin{tabular}{|llll|}
\hline & Pollen viability & ROS content & NO content \\
\hline Pollen viability & 1.000 & & \\
\hline ROS content & $-0.742^{\star}$ & 1.000 & \\
\hline NO content & $-0.740^{\star}$ & $0.854^{\star \star}$ & 1.000 \\
\hline
\end{tabular}

Notes: * was significantly correlated at 0.05 level; ** was significantly correlated at 0.01 level. Changes in viability, ROS and NO contents in pollen with and without exogenous ROS regulator treatments after cryopreservation

The ROS scavengers AsA and GSH at appropriate concentrations not only significantly increased pollen viability after LN storage (Fig. 2-A) but also significantly inhibited the endogenous ROS content (Fig. 3- A, 
$B, C, D)$. At the same time, the addition of the ROS scavengers AsA and GSH significantly reduced the endogenous NO content of pollen $(P<0.05), 31.23 \%$ and $25.96 \%$ lower than that without ROS scavenger treatment (Fig. 3- E, F, G, H).

\section{Changes in viability, ROS and NO contents in pollen with and without exogenous NO regulator treatments after cryopreservation}

The appropriate concentration of the NO carrier SNP had a significant inhibitory effect on the pollen viability after LN storage (Fig. 2- B) but increased the content of endogenous NO, while the addition of the NO scavenger c-PTIO increased the pollen viability after preservation with LN and significantly inhibited the content of endogenous NO (Fig. 4- A, B, C, D). In addition, the addition of an appropriate concentration of NO carrier SNP after LN storage significantly increased the ROS content of pollen $(P<0.05)$, while the addition of the NO scavenger c-PTIO significantly inhibited the accumulation of endogenous ROS in pollen after $L N$ storage (Fig. 4- E, F, G, H).

\section{Changes in NO related genes and substances in pollen with and without exogenous ROS regulator treatments after cryopreservation}

Compared with LN-preserved pollen, the addition of the ROS scavenger AsA after preservation with LN significantly downregulated the expression of CSU2 (Fig. 5-B), which is a regulatory gene in the NOS biosynthesis pathway, but it had no significant effect on the expression of NIA and CYP94A1 (Fig. 5-A, C), regulatory genes of the nitrate reductase biosynthesis pathway, while the addition of GSH had no significant effect on the expression of these three genes (Fig. 5).

The ROS scavengers AsA and GSH had significant inhibitory effects on the activities of NOS-like enzymes after cryopreservation $(P<0.05)$, which were decreased by $51.16 \%$ and $54.59 \%$ compared with the $L N$ preserved pollen without treatment, respectively (Fig. 6).

\section{Changes in ROS related genes and substances in pollen with and without exogenous NO regulator treatments after cryopreservation}

After cryopreservation, the addition of exogenous NO carrier SNP significantly upregulated the expression levels of the RBOHJ, CAT1, DHAR2 and GSTU8 genes but significantly downregulated the expression levels of $A P X 3, G P X 6$ and $G S H 2$. However, the addition of the NO scavenger c-PTIO after cryopreservation significantly downregulated the expression levels of RBOHJ, SODA, APX3, DHAR2, GSTU8, GPX6, and GSH2 but had no significant effect on the expression levels of CAT1 (Fig. 7).

The addition of exogenous NO carrier SNP after LN storage significantly promoted the activation of NADPH enzymes $(P<0.05)$, and the addition of the NO scavenger c-PTIO significantly inhibited the activity of NADPH enzymes (Fig. 8). After cryopreservation, the appropriate concentration of NO carrier SNP significantly inhibited the activities of the enzyme ROS scavenging substances CAT, APX, and GR and the content of the nonenzyme ROS scavenging substance AsA $(P<0.05)$ but significantly increased the SOD activity of pollen. However, the addition of the NO scavenger c-PTIO not only significantly 
improved the activities of the enzyme scavengers CAT, APX and GR (Fig. 9-B, C, D) but also significantly promoted the accumulation of nonenzymatic AsA and GSH (Fig. 9-E, F).

\section{Discussion}

\section{Effects of ROS on NO and its pathways in pollen cryopreservation}

A large number of studies have shown that ROS are involved in the regulation of NO production. In a study of Medicago truncatula under low-temperature stress, $\mathrm{H}_{2} \mathrm{O}_{2}$ treatment accelerated the accumulation of NO, which played a key role in improving the efficiency of replacing oxidase (AOX) and alleviating the damage to the photosystem under low-temperature stress (Arfan et al., 2019). In the root development of Arabidopsis thaliana, exogenous $\mathrm{H}_{2} \mathrm{O}_{2}$ increased $\mathrm{NO}$ levels by 8 times (Wang et al., 2010). Exogenous $\mathrm{H}_{2} \mathrm{O}_{2}$ also triggered NO production in guard cells and other leaf cells of Phaseolus aureus (Lum et al., 2002). In this study, exogenous ROS scavengers AsA and GSH at appropriate concentrations significantly reduced the endogenous NO content of pollen after cryopreservation (Fig. 3$\mathrm{E}, \mathrm{F}, \mathrm{G}, \mathrm{H})$. ROS were involved in the regulation of intracellular NO content during cryopreservation of $P$. lactiflora pollen.

The biosynthesis of $\mathrm{NO}$ in plant cells during the stress response was mainly achieved through the Larginine-dependent and nitrate reductase pathways (Ma and Berkowitz, 2016). Among them, the NOS-like enzyme synthesis pathway dependent on L-arginine is the most widely studied (Leitner et al., 2009). Although nitric oxide synthase (NOS) has not been found in plants, it has been reported that NOS inhibitors have a significant inhibitory effect on NO signaling in plants, indicating the existence of NOS enzymes in plants similar to those found in mammals (Tewari et al., 2013). Previous studies have shown that the accumulation of $\mathrm{H}_{2} \mathrm{O}_{2}$ induces $\mathrm{NO}$ production by increasing the expression of nitrate reductase involved in NO biosynthesis (Lin et al., 2012; Wang et al., 2013). However, in this study, the addition of ROS scavengers AsA and GSH at appropriate concentrations did not significantly affect the regulatory genes involved in the nitrate reduction pathway for NO biosynthesis. Only AsA significantly downregulated the expression level of the regulatory gene CSU2 involved in the NOS-like enzyme biosynthesis pathway that is dependent on L-arginine (Fig. 5), while ROS scavenging agents at appropriate exogenous concentrations significantly reduced the activities of NOS-like enzymes in cryopreserved pollen at the biochemical level (Fig. 6). These results indicate that in pollen cryopreservation, ROS participate in the regulation of intracellular NO content, which mainly acts on NOSlike enzymes involved in NO biosynthesis.

\section{Effects of NO on ROS and its pathways in pollen cryopreservation}

To date, a large number of studies have shown that changes in NO play an important role in ROS changes in cells. Xiao (2014) found that NO played a positive regulatory role on ROS in Cucumis sativus seedlings under cold stress. Jiang (2019b) found that NO produced a positive effect on ROS content during the preculture stage of vitrification-cryopreservation in Dendrobium protocorm-like bodies. 
However, some studies have found that NO plays a negative regulatory role in the accumulation of ROS. $\mathrm{He}$ (2019) found that the addition of NO carrier SNP reduced the excess $\mathrm{H}_{2} \mathrm{O}_{2}$ in the root tips of Arachis hypogaea during the process of aluminum stress-induced PCD, while the addition of NO scavenger CPTIO produced the opposite effect. This difference in NO regulation of endogenous ROS in botanical cells may be due to the dual role of NO in the occurrence of physiological and biochemical phenomena, which depends on a variety of factors, such as cell type, cell redox status, and local NO flux and dose (Wang et al., 2010), but the specific mechanisms causing the regulatory differences remains to be further explored. In this study, the addition of an appropriate concentration of NO carrier SNP after LN storage significantly promoted the accumulation of endogenous ROS, while the addition of an appropriate concentration of NO scavenger c-PTIO significantly reduced the content of endogenous ROS (Fig. 4- E, F, G, H). NO plays a positive role in the regulation of intracellular ROS accumulation during pollen cryopreservation. This is consistent with the findings of Jiang (2019b) in the cryopreservation of Dendrobium nobile procorms. When the intracellular concentration of $\mathrm{NO}$ decreased, the accumulation of $\mathrm{H}_{2} \mathrm{O}_{2}$ also significantly decreased, indicating that NO plays a positive regulatory role in ROS.

In the plant response to stress, previous studies showed that NADPH oxidase involved in ROS production was one of the key pathways involved in NO regulation of intracellular ROS concentration. Yun (2011), in plant immune reactions, found that NO affected ROS synthesis through S-nitrosolation NADPH oxidase. Wang's (2013) study also showed that NO might control the production of ROS through protein Snitrosylation. In this study, it was found that the addition of NO carrier SNP significantly promoted the activation of NADPH oxidase and upregulated the regulatory gene $R B O H J$ in pollen after LN storage, and the addition of the NO scavenging agent C-PTIO after preservation with LN inhibited the activity of $\mathrm{NADPH}$ oxidase and the relative expression of its regulatory gene $\mathrm{RBOHJ}$ (Fig. 7-8). These results indicate that NO participates in the regulation of endogenous ROS accumulation by acting on NADPH oxidase during pollen cryopreservation.

In addition, the antioxidant system may be another key pathway by which NO regulates the intracellular ROS concentration. Murgia (2004), in callus suspension cells of Arabidopsis thaliana and Nicotiana tobacum, found that NO carrier SNP inhibited the ROS scavenging system, thus accelerating intracellular ROS accumulation. Similarly, NO carrier SNP inhibited antioxidant enzymes in Zinnia elegans xylem (Ferrer and Ros Barceló, 1999), and a similar inhibitory effect of SNP on antioxidant enzymes in the leaves damaged Solanum tuberosum (Beligni and Lamattina, 2002) and reduced the endogenous ROS content. In this study, it was found that the addition of an appropriate concentration of NO carrier SNP after LN storage had significant inhibitory effects on the ROS scavenging substances CAT, APX, GR and AsA and significantly downregulated the expression levels of the related regulatory genes $A P X 3, G P X 6$ and $\mathrm{GSH} 2$; additionally, the addition of the NO scavenging agent c-PTIO significantly promoted the accumulation of CAT, APX, GR, AsA and GSH and had a certain downregulatory effect on the expression levels of the antioxidant-related regulatory genes SODA, APX3, DHAR2, GSTU8, GPX6 and GSH2 (Figs. 7, 9). This result suggested that during the cryopreservation of pollen, NO regulated endogenous ROS content mainly by affecting CAT activity and the related substrates of the AsA-GSH circulatory system. 
This is consistent with the findings of Jiang (2019b) in the cryopreservation of protocorms from Dendrobium nobile. NO participated in the regulation of endogenous ROS changes by affecting the activity of endogenous ROS scavenging substances, thus participating in the changes in viability.

In summary, there was an interactive relationship between ROS and NO in pollen cryopreservation, which is consistent with a large number of existing research results (de Pinto et al., 2002; Neill et al., 2002; Zaninotto et al., 2006). The regulation of NO content by ROS was mainly mediated by NOS-like enzymes involved in NO biosynthesis; the effect of NO on ROS was mainly mediated through the action of NADPH oxidase involved in ROS generation and the AsA-GSH antioxidant cycle involved in ROS scavenging. This is consistent with the findings of Murgia (2004) in suspension cells of Arabidopsis thaliana and Nicotiana tobacum and Arfan (2019) in Medicago truncatula under low temperature stress.

\section{Conclusion}

This study first investigated the interaction and its pathways between ROS and NO during pollen cryopreservation. There was a two-way interaction between ROS and NO during pollen cryopreservation. Among them, the NADPH oxides involved in ROS production and the antioxidant cycling systems of AsAGSH and CAT responsible for intracellular ROS scavenging were the key sites of NO-regulated changes in ROS; the biosynthesis pathway of NOS-like enzymes involved in NO production was one of the important pathways by which ROS regulated changes in endogenous NO content.

\section{Declarations}

Acknowledgements: This research was supported by the National Natural Science Foundation of China (No. 31770741). And we thank Jiao Pengcheng and Ji Jiaojiao (Core Facility, Center of Biomedical Analysis, Tsinghua University) for technical support with flow cytometry analysis.

Conflict of interest: The authors declare that they have no conflict of interest.

Author contribution statement: Ruifen Ren designed the research, completed the experiments囚analyzed the data and drafted the manuscript. Hao Zhou offered some help on the material collection. Lingling Zhang offered some help on the technical aspects of the experiment. Xueru Jiang offered some help on the research design. Yan Liu conceived the project, supervised the analysis and critically revised the manuscript. All authors read and approved the manuscript.

\section{References}

1. Arfan M, Zhang DW, Zou LJ, Luo SS, Tan WR, Zhu T, Lin HH (2019) Hydrogen peroxide and nitric oxide crosstalk mediates brassinosteroids induced cold stress tolerance in Medicago truncatula. Int J Mol Sci 20:144. doi.org/10.3390/ijms20010144

2. Beligni MV, Lamattina L (2002) Nitric oxide interferes with plant photo-oxidative stress by detoxifying reactive oxygen species. Plant Cell and Environment 25:737-748. doi.org/10.1046/j.1365- 
3040.2002.00857.x

3. Borghezan M, Clauman AD, Steinmacher DA, Guerra MP, Orth AI (2011) In vitro viability and preservation of pollen grain of kiwi (Actinidia chinensis var. deliciosa (A. Chev.) A. Chev). Crop Breeding and Applied Biotechnology 11:338-344. doi.org/10.1590/s1984-70332011000400007

4. Da Silva D, Lachaud C, Cotelle V, Brière C, Grat S, Mazars C, Thuleau P (2011) Nitric oxide production is not required for dihydrosphingosine-induced cell death in tobacco BY-2 cells. Plant Signal Behav 6(5):736-739. doi.org/10.4161/psb.6.5.15126

5. de Pinto MC, Tommasi F, De Gara L (2002) Changes in the antioxidant systems as part of the signaling pathway responsible for the programmed cell death activated by nitric oxide and reactive oxygen species in tobacco Bright-Yellow 2 cells. Plant Physiol 130:698-708. doi.org/10.1104/pp.005629

6. Dinato NB, Santos IRI, Leonardecz E, Burson BL, Quarín CL, Paula AF, Fávero AP (2018) Storage of bahiagrass pollen at different temperatures. Crop Sci 58:2391-2398. doi.org/10.2135/cropsci2018.03.0164

7. Dmura M, Akihama T, Rome AGP (1980) Pollen preservation of fruit trees for genebanks in Japan. Plant Genetic Resources Newsletter, pp 4328-4331

8. Engelmann F (2004) Plant cryopreservation: Progress and prospects. In Vitro Cellular \& Developmental Biology-Plant, 40(5): 427-433. doi.org/10.1079/IVP2004541

9. Esim N, Atici O (2014) Nitric oxide improves chilling tolerance of maize by affecting apoplastic antioxidative enzymes in lesves. Plant Growth Regul 72(1):29-38. doi.org/10.1007/s10725-0139833-4

10. Ferrer Nakashima T, Sekiguchi T, Kuraoka A, Fukushima K, Shibata Y, Komiyama S, Nishimoto T (1993) Molecular cloning of a human Cdna encoding a novel protein, DAD1, whose defect causes apoptotic cell death in hamster BHK21 cells. Mol Cell Biol 13:6367-6374. doi.org/10.1128/mcb.13.10.6367-6374.1993

11. Griffith OW (1980) Determination of glutathione and glutathione disulfide using glutathione reductase and 2-vinylpyridine. Anal Biochem 106(1):201-212. doi.org/10.1016/00032697(80)90139-6

12. He HY, Oo TL, Huang WJ, He LF, Gu MH (2019) Nitric oxide acts as an antioxidant and inhibits programmed cell death induced by aluminum in the root tips of peanut (Arachis hypogaea L.). Sci Rep 9(1):9516. doi.org/10.1038/s41598-019-46036-8

13. Jiang XR, Ren RF, Di W, Jia MX, Li ZD, Liu Y, Gao RF (2019a) Hydrogen peroxide and nitric oxide are involved in programmed cell death induced by cryopreservation in Dendrobium protocorm-like bodies. Plant Cell, Tissue and Organ Culture (PCTOC) 137:553-563. doi.org/10.1007/s11240-01901590-x

14. Jiang XR (2019b) Study on the mechanism of programmed cell death during vitrificationcryopreservation in Dendrobium protocorm-like bodies. Dissertation, Beijing Forsetry University (in Chinses). DOI: 10.26949/d.cnki.gblyu.2019.000023 
15. Kampfenkel K, Montagu MV, Inzé D (1995) Extraction and determination of ascorbate and dehydroascorbate from plant tissue. Anal Biochem 225:165-167. doi.org/10.1006/abio.1995.1127

16. Leitner M, Vandelle E, Gaupels F, Bellin D, Delledonne M (2009) NO signals in the haze: nitric oxide signalling in plant defence. Curr Opin Plant Biol 12(4):451-458. doi.org/10.1016/j.pbi.2009.05.012

17. Lin A, Wang Y, Tang J, Xue P, Li C, Liu L, Hu B, Yang F, Loake GJ, Chu C (2012) Nitric oxide and protein S-nitrosylation are integral to hydrogen peroxide-induced leaf cell death in rice. Plant Physiol 158(1):451-464. doi.org/10.1104/pp.111.184531

18. Li GQ (2005) Sutdies on Cryopreservation of Camellia Pollen, Dissertation, Beijing Forestry University (in Chinese)

19. Li BL (2010) Studies on differentially expressed protein of pollen cryopreservation and cryobank construction of Paeonia spp, Dissertation, Beijing Forestry University (in Chinese)

20. Li HS, Sun Q, Zhao SJ, Zhang WH (2000) Assay of malondialdehyde in plants. Experiment principle and technology of plant physiology and biochemistry. Higher Education Press, Beijing, pp 260-261. (in Chinese).

21. Li ZD (2019) Evaluation of long-term cryopreservation effect of ornamental plants pollen and study of the physiological mechanism, Dissertation, Beijing Forestry University (in Chinese)

22. Lum HK, Butt YK, Lo SC (2002) Hydrogen peroxide induces a rapid production of nitric oxide in mung bean (Phaseolus aureus). Nitric Oxide 6(2):205-213. doi.org/10.1006/niox.2001.0395

23. Ma Y, Berkowitz GA (2016) NO and $\mathrm{Ca}^{2+}$ : critical components of cytosolic signaling systems involved in stomatal immune responses. Advances in Botanical Research 77:285-323. doi.org/10.1016/bs.abr.2015.11.001

24. Mercier SEP (1995) The role of a pollen bank in the tree genetic improvement program in Quebec (Canada). Grana 34:367-370. doi.org/10.1080/00173139509429468

25. Murgia I, de Pinto MC, Delledonne M, Soave C, Gara LD (2004) Comparative effects of various nitric oxide donors on ferritin regulation, programmed cell death, and cell redox state in plant cells. J Plant Physiol 161(7):777-783. doi.org/10.1016/j.jplph.2003.12.004

26. Nakano $Y$, Asada K (1981) Hydrogen peroxide is scavenged by ascorbate-specific peroxidase in spinach chloroplasts. Plant Cell Physiol 22(5):867-880.

doi.org/10.1093/oxfordjournals.pcp.a076232

27. Neill S, Desikan R, Hancock J (2002) Hydrogen peroxide signalling in stomatal guard cells. Curr Opin Plant Biol 5:388-395. doi.org/10.1016/s1369-5266(02)00282-0

28. Prochazkova D, Sairam RK, Srivastava GC, Singh DV (2001) Oxidative stress and antioxidant activity as the basis of senescence in maize leaves. Plant Sci 161:765-771. doi.org/10.1016/S01689452(01)00462-9

29. Ren RF, Li ZD, Li BL, Xu J, Jiang XR, Liu Y, Zhang KY (2019a) Changes of pollen viability of ornamental plants after long-term preservation in a cryopreservation pollen bank. Cryobiology 89:14-20. doi.org/10.1016/j.cryobiol.2019.07.001 
30. Ren RF, Li ZD, Jiang XR, Liu Y (2020b) The ROS-associated programmed cell death causes the decline of pollen viability recovered from cryopreservation in Paeonia lactiflora. Plant Cell Rep 39:941-952. doi.org/10.1007/s00299-020-02540-0

31. Ren RF, Jiang XR, Di W, Li ZD, Li BL, Xu J, Liu Y (2019b) HSP70 improves the viability of cryopreserved Paeonia lactiflora pollen by regulating oxidative stress and apoptosis-like programmed cell death events. Plant Cell, Tissue and Organ Culture (PCTOC) 139:53-64. doi.org/10.1007/s11240-019-01661-z

32. Ren RF, Zhou H, Zhang LL, Jiang XR, Liu Y (2021) Cryopreserved-pollen viability is regulated by NOinduced programmed cell death. Plant Cell Reports. doi.org/10.1007/s00299-021-02779-1

33. Souza EH, Souza FVD, Rossi ML, Brancalleão N, da Silva Ledo CA, Martinelli AP (2015) Viability, storage and ultrastructure analysis of Aechmea bicolor (Bromeliaceae) pollen grains, an endemic species to the Atlantic forest. Euphytica 204(1):13-28. doi.org/10.1007/s10681-014-1273-3

34. Tewari RK, Prommer J, Watanabe M (2013) Endogenous nitric oxide generation in protoplast chloroplasts. Plant Cell Rep 32:31-44. doi.org/10.1007/s00299-012-1338-5

35. Wan YL, Hong AY, Zhang YX, Liu Y (2019) Selection and validation of reference genes of Paeonia lactiflora in growth development and light stress. Physiology and Molecular Biology of Plants 25(4):1097-1105. doi.org 10.1007/s12298-019-00684-2

36. Wang J, Li X, Liu Y, Zhao X (2010) Salt stress induces programmed cell death in Thellungiella halophile suspension-cultured cells. J Plant Physiol 167(14):1145-1151. doi.org/10.1016/j.jplph.2010.03.008

37. Wang LL, Zhu XP, Liu JW, Chu XJ, Jiao J, Liang YC (2013) Involvement of phospholipases C and D in the defence response of riboflavin-treated tobacco cells. Protoplasma 250(2):441-449. doi.org/10.1007/s00709-012-0426-2

38. Wilkins KA, Bancroft J, Bosch M, Ings J, Smirnoff N, Franklin-Tong VE (2011) Reactive Oxygen Species and Nitric Oxide Mediate Actin Reorganization and Programmed Cell Death in the SelfIncompatibility Response of Papaver. Plant Physiol 156:404-416. doi.org/10.1104/pp.110.167510

39. Xu J (2014) A study on the mechanism of Magnolia denudata pollen cryopreservation, Dissertation, Beijing Forestry University (in Chinese)

40. Xu J, Li BL, Liu Q, Shi Y, Peng JG, Jia MX, Liu Y (2014) Wide-scale pollen banking of ornamental plants through cryopreservation. Cryoletters 35:312-319

41. Xiao CY Regulation of nitric oxide on photosynthetic carbon assimilation mechanism in cucumber seedlings under low temperature stress, Dissertation, Shihezi University (in Chinese)

42. Yun BW, Feechan A, Yin M, Saidi NB, Le Bihan T, Yu M, Moore JW, Kang JG, Kwon E, Spoel SH, Pallas JA, Loake GJ (2011) S-nitrosylation of NADPH oxidase regulates cell death in plant immunity. Nature 478:264-268. doi.org/10.1038/nature10427

43. Zaninotto F, La Camera S, Polverari A, Delledonne M (2006) Cross talk between reactive nitrogen and oxygen species during the hypersensitive disease resistance response. Plant Physiol 141(2):379383. doi.org/10.1104/pp.106.078857 
44. Zhang L, Chang W, Wei Y, Liu L, Wang Y (1993) Cryopreservation of ginseng pollen. HortScience 28(7):742-743. doi.org/10.21273/HORTSCl.28.7.742

45. Zhang D, Ren L, Chen GQ, Zhang J, Reed BM, Shen XH (2015) ROS-induced oxidative stress and apoptosis-like event directly affect the cell viability of cryopreserved embryogenic callus in Agapanthus praecox. Plant Cell Rep 34(9):1499-1513. doi.org/10.1007/s00299-015-1802-0

46. Zhang HY, Wang WX, Yin H, Zhao XM, Du YG (2012) Oligochitosan induces programmed cell death in tobacco suspension cells. Carbohydr Polym 87:2270-2278. doi.org/10.1016/j.carbpol.2011.10.059

47. Zhang YL (2007) Pollen cryopreservation of Prunus mume Sieb. et. Zuce. and the conslruction of pollen bank, Dissertation, Beijing Forestry University (in Chinese)

\section{Figures}
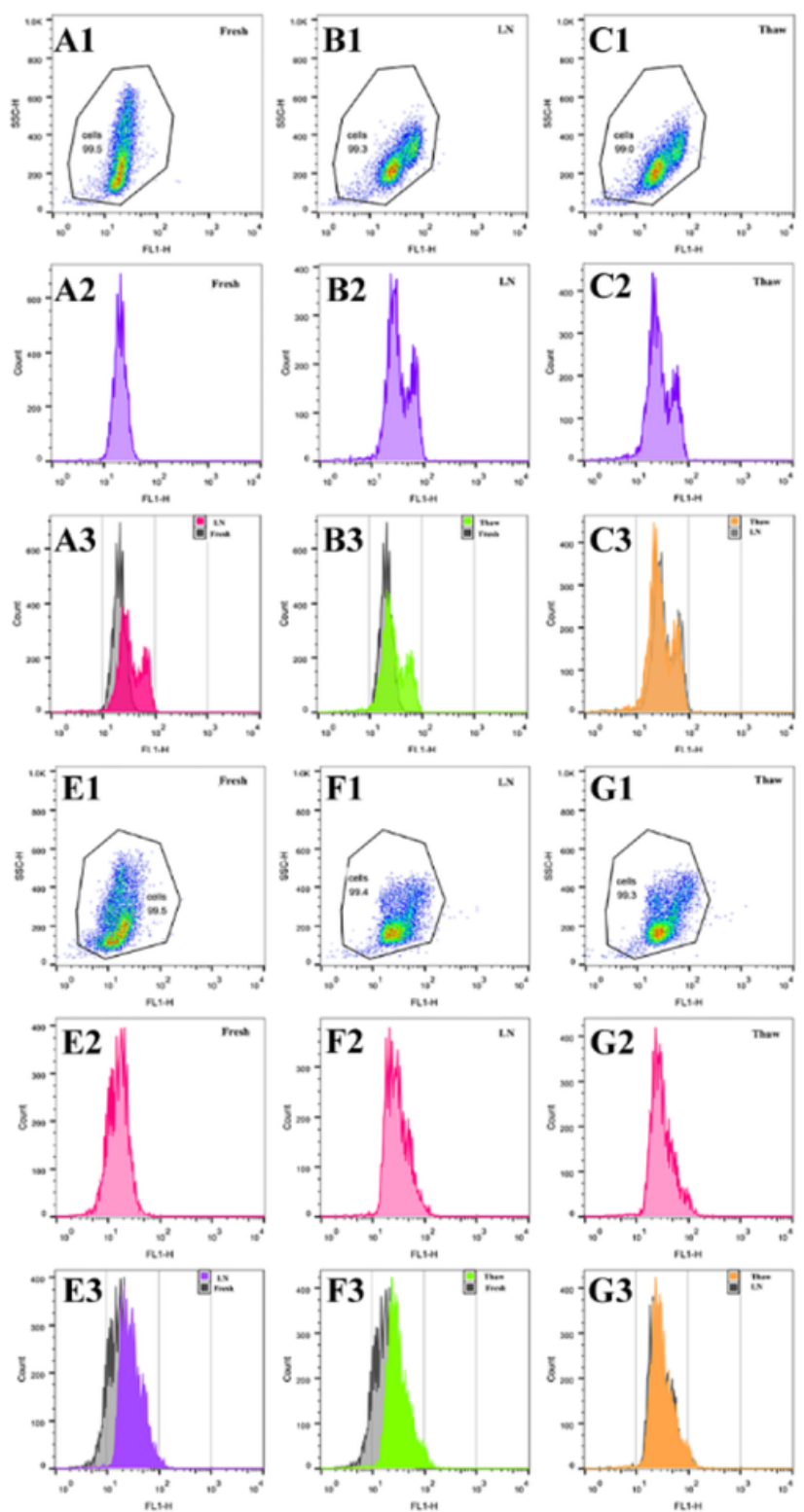
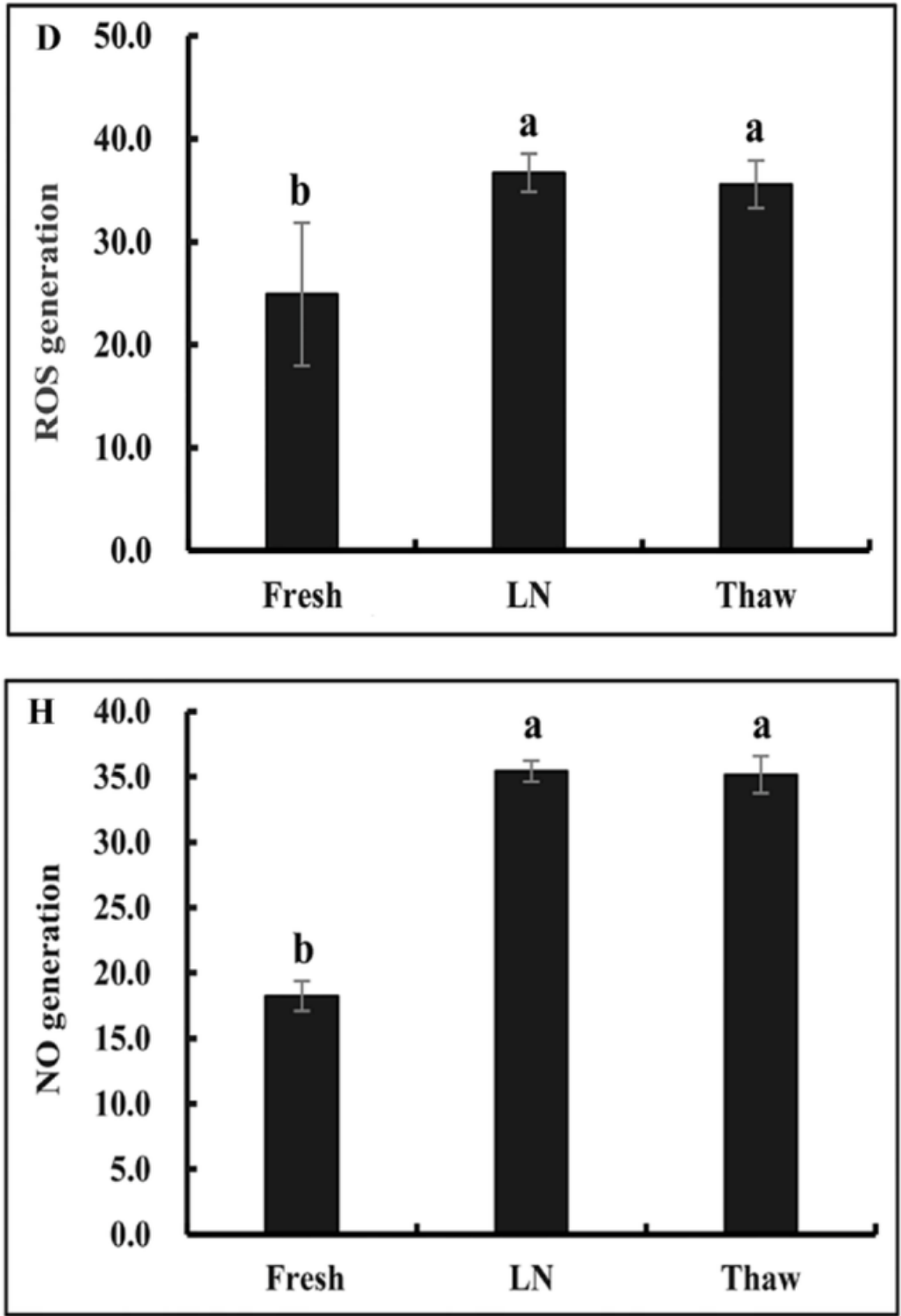

Figure 1 
Changes in ROS and NO contents in P. lactiflora pollen before and after cryopreservation. Notes: The significant difference was based on the 0.05 level. A: Fresh pollen; B: Pollen thawed at room temperature after cryopreservation; C: Pollen thawed with running water after cryopreservation; D: ROS content; E: Fresh pollen; F: Pollen thawed at room temperature after cryopreservation; G: Pollen thawed with running water after cryopreservation; $\mathrm{H}$ : NO content. 1: the flow cytometry maps; 2 : the flow spectrogram of fluorescence; 3 : the comparison spectrograms. Fresh: fresh pollen without cryopreservation; LN: pollen thawed at room temperature after cryopreservation; Thaw: pollen thawed with running water after cryopreservation.
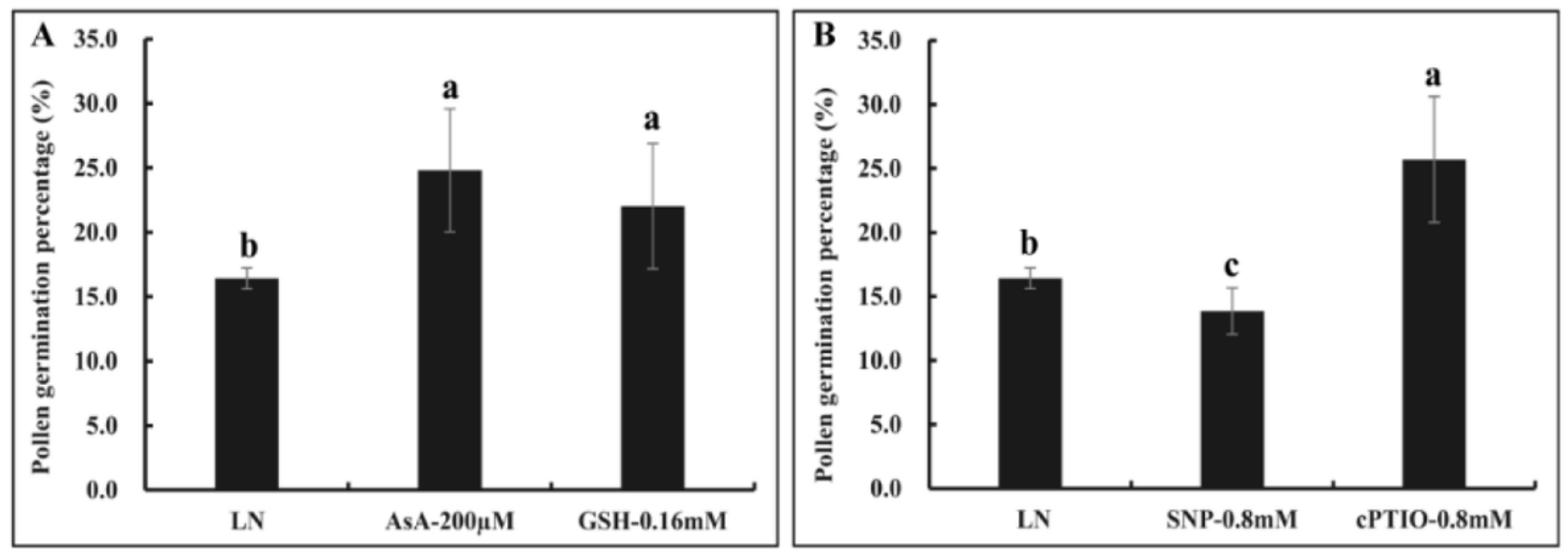

Figure 2

Changes in pollen viability in P. lactiflora with and without exogenous ROS and NO regulator treatments after cryopreservation. Notes: The significant difference was based on the 0.05 level. A: Pollen viability changes with and without ROS regulator treatments after cryopreservation; B: Pollen viability changes with and without NO regulator treatments after cryopreservation. LN: pollen thawed at room temperature after cryopreservation; AsA-200 $\mu \mathrm{M}$ : pollen supplemented with $200 \mu \mathrm{M}$ AsA after cryopreservation; GSH$0.16 \mathrm{mM}$ : pollen supplemented with $0.16 \mathrm{mM}$ GSH after cryopreservation; SNP- $0.8 \mathrm{mM}$ : pollen supplemented with $0.8 \mathrm{mM}$ SNP after cryopreservation; CPTIO- $0.8 \mathrm{mM}$ : pollen supplemented with 0.8 $\mathrm{mM}$ CPTIO after cryopreservation. 

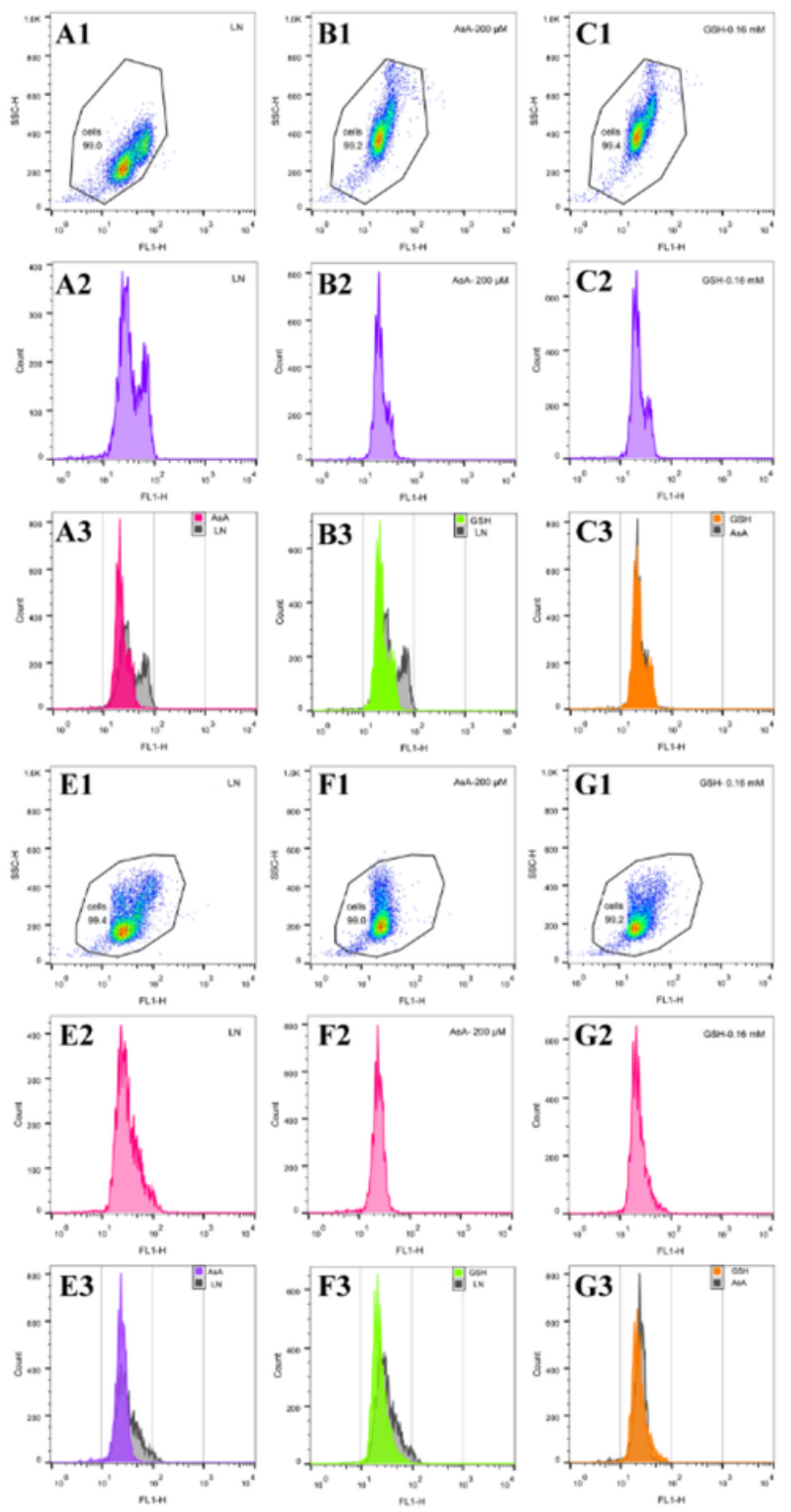
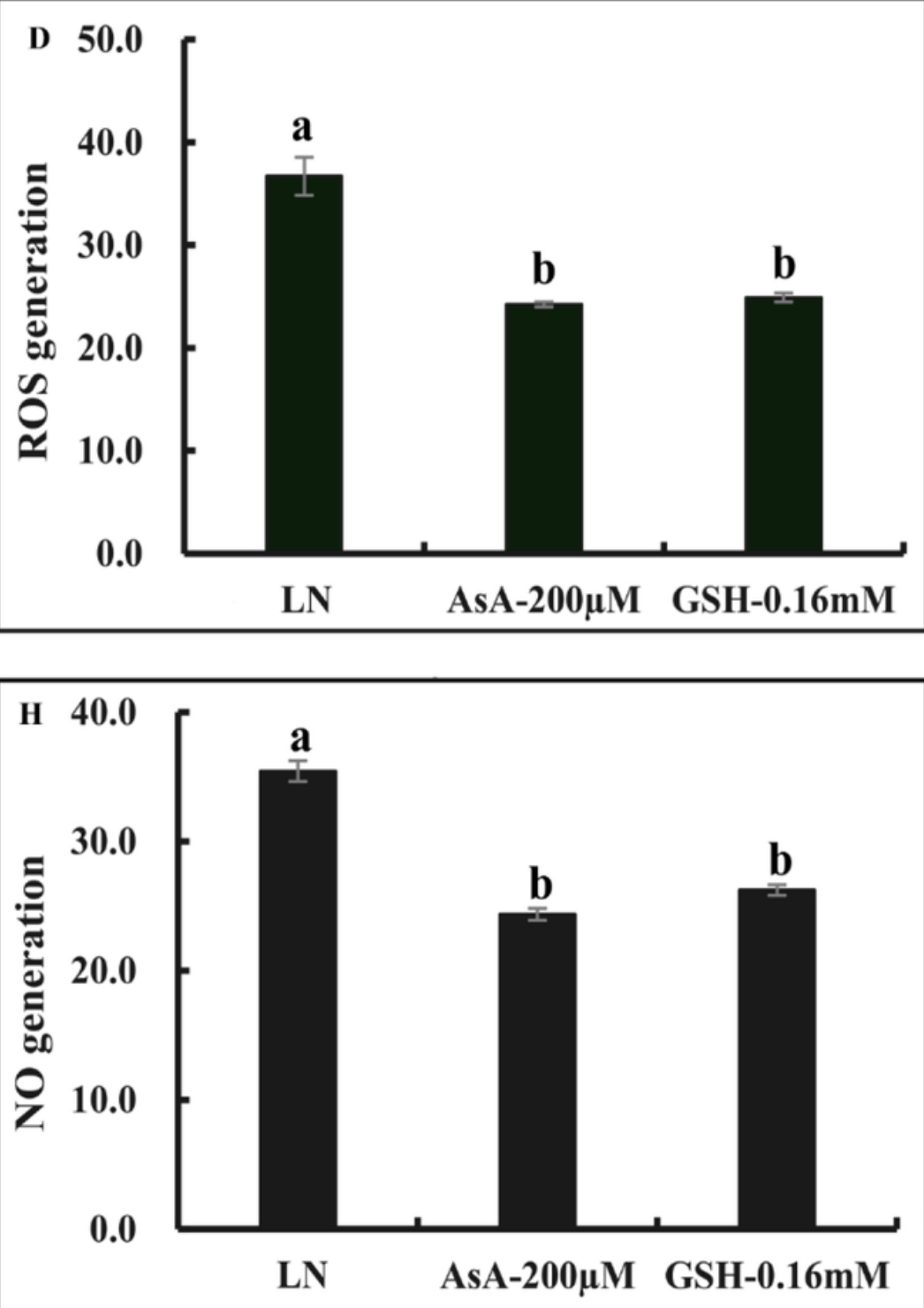

Figure 3

Changes in pollen endogenesis ROS and NO content in P. lactiflora with and without exogenous ROS regulator treatments after cryopreservation. Notes: The significant difference was based on the 0.05 level. A: Pollen thawed at room temperature after cryopreservation; B: Pollen supplemented with $200 \mu \mathrm{M}$ AsA after cryopreservation; C: Pollen supplemented with $0.16 \mathrm{mM} \mathrm{GSH}$ after cryopreservation; D: ROS content; E: Pollen thawed at room temperature after cryopreservation; F: Pollen supplemented with $200 \mu \mathrm{M}$ AsA after cryopreservation; G: Pollen supplemented with $0.16 \mathrm{mM} \mathrm{GSH}$ after cryopreservation; $\mathrm{H}$ : NO content. 1 : the flow cytometry maps; 2 : the flow spectrogram of fluorescence; 3 : the comparison spectrograms. $\mathrm{LN}$ : pollen thawed at room temperature after cryopreservation; AsA-200 $\mu \mathrm{M}$ : pollen supplemented with $200 \mu \mathrm{M}$ AsA after cryopreservation; GSH- $0.16 \mathrm{mM}$ : pollen supplemented with $0.16 \mathrm{mM} \mathrm{GSH}$ after cryopreservation. 

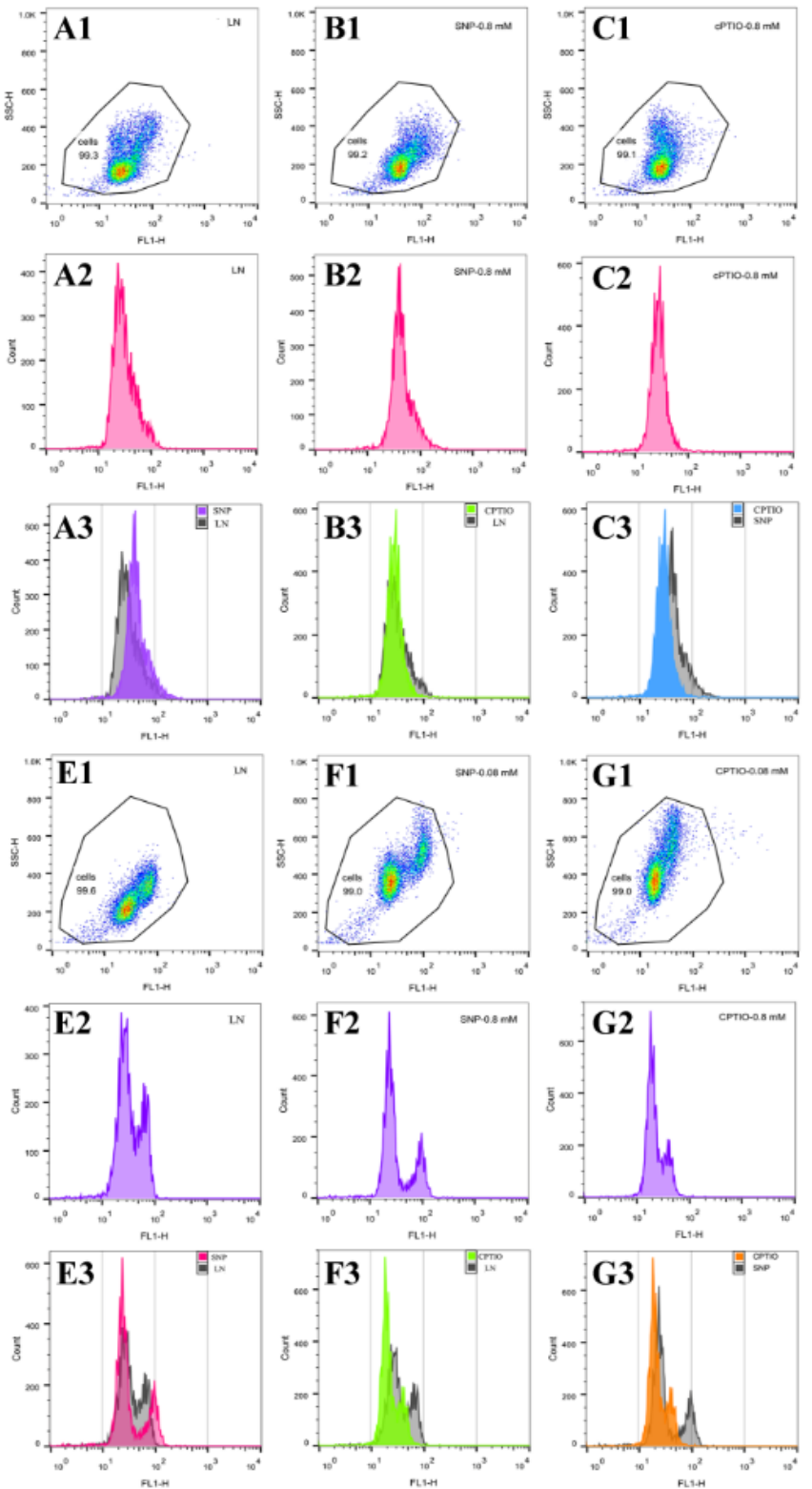
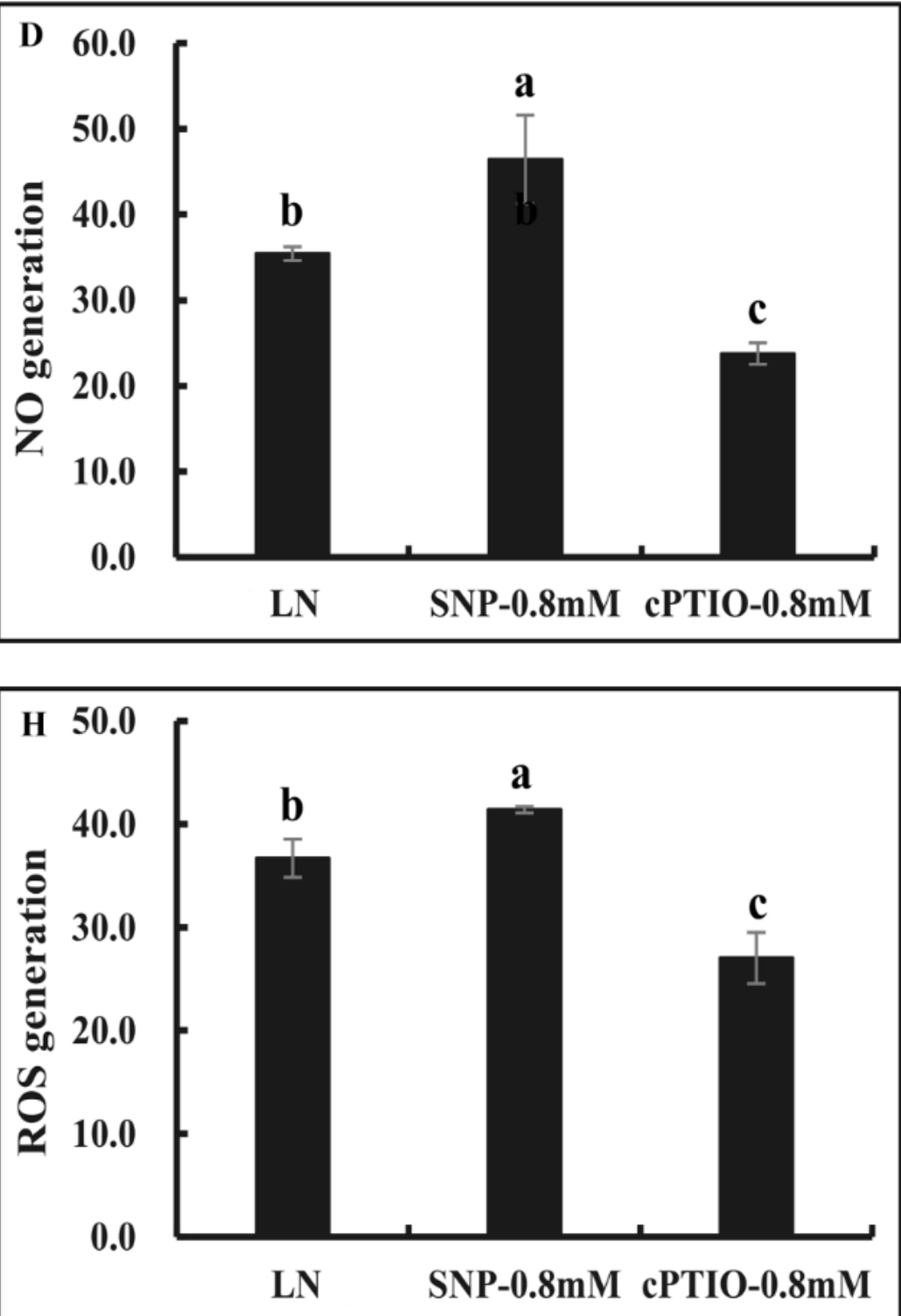

Figure 4

Changes in pollen endogenesis ROS and NO content in P. lactiflora with and without exogenous NO regulator treatments after cryopreservation. Notes: The significant difference was based on the 0.05 level. A: Pollen thawed at room temperature after cryopreservation; B: Pollen supplemented with $0.8 \mathrm{mM}$ SNP after cryopreservation; C: Pollen supplemented with $0.8 \mathrm{mM}$ cPTIO after cryopreservation; D: NO content; E: Pollen thawed at room temperature after cryopreservation; F: Pollen supplemented with $0.8 \mathrm{mM} \mathrm{SNP}$ after cryopreservation; G: Pollen supplemented with $0.8 \mathrm{mM}$ cPTIO after cryopreservation; H: ROS content. 1 : the flow cytometry maps; 2 : the flow spectrogram of fluorescence; 3 : the comparison spectrograms. LN: pollen thawed at room temperature after cryopreservation; SNP- $0.8 \mathrm{mM}$ : pollen supplemented with $0.8 \mathrm{mM}$ SNP after cryopreservation; CPTIO- $0.8 \mathrm{mM}$ : pollen supplemented with 0.8 $\mathrm{mM}$ cPTIO after cryopreservation. 

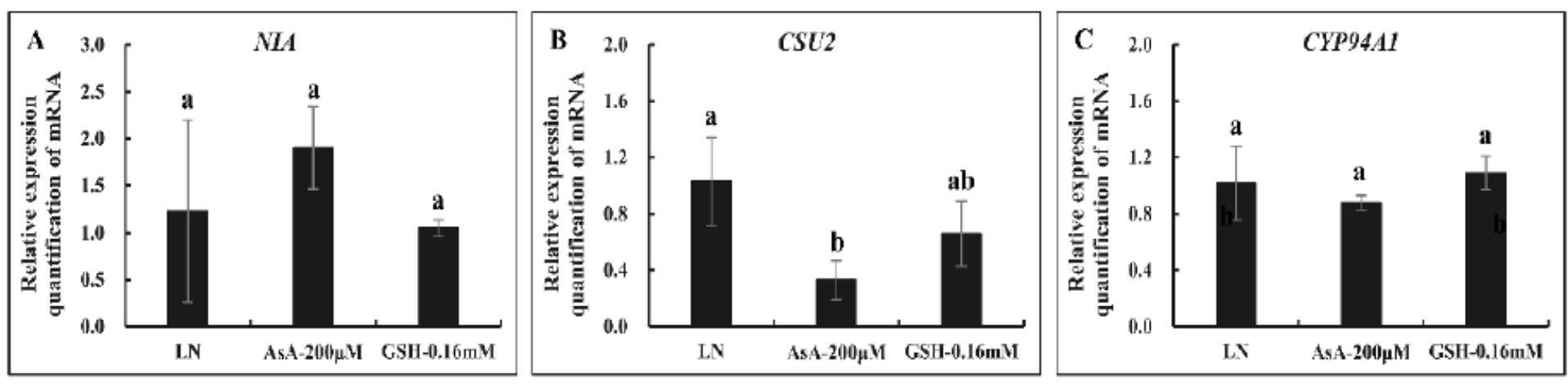

\section{Figure 5}

Changes in NO related genes in P. lactiflora pollen with and without exogenous ROS regulator treatments after cryopreservation. Notes: The significant difference was based on the 0.05 level. A: NIA; B: CSU2; C: CYP94A1. LN: pollen thawed at room temperature after cryopreservation; AsA-200 $\mu \mathrm{M}$ : pollen supplemented with $200 \mu \mathrm{M}$ AsA after cryopreservation; GSH- $0.16 \mathrm{mM}$ : pollen supplemented with 0.16 mM GSH after cryopreservation.
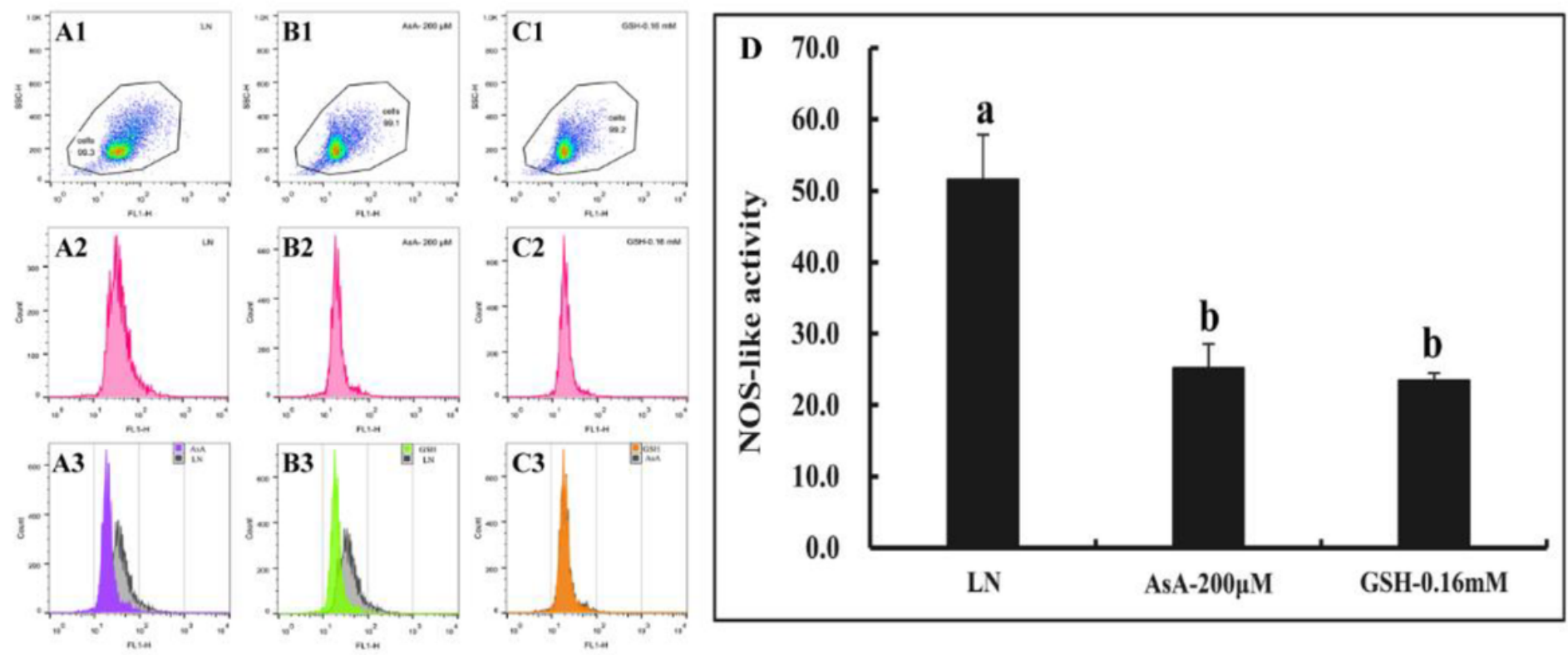

Figure 6

Changes in NOS-like enzyme in P. lactiflora pollen with and without exogenous ROS regulator treatments after cryopreservation. Notes: The significant difference was based on the 0.05 level. A: Pollen thawed at room temperature after cryopreservation; B: Pollen supplemented with $200 \mu \mathrm{M}$ AsA after cryopreservation; C: Pollen supplemented with $0.16 \mathrm{mM} \mathrm{GSH}$ after cryopreservation; D: activity of NOS-like enzyme. 1: the flow cytometry maps; 2 : the flow spectrogram of fluorescence; 3 : the comparison spectrograms. LN: pollen thawed at room temperature after cryopreservation; AsA-200 $\mu \mathrm{M}$ : pollen supplemented with 200 $\mu \mathrm{M}$ AsA after cryopreservation; GSH- $0.16 \mathrm{mM}$ : pollen supplemented with $0.16 \mathrm{mM} \mathrm{GSH}$ after cryopreservation. 

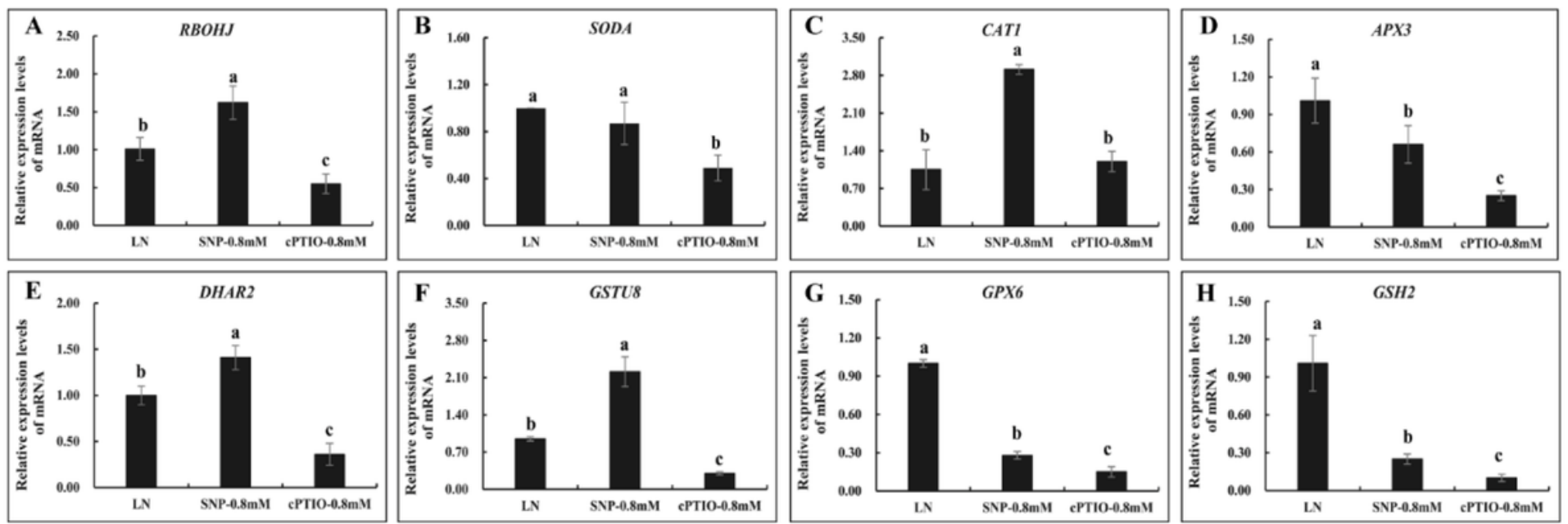

Figure 7

Changes in ROS related genes in P. lactiflora pollen with and without exogenous NO regulator treatments after cryopreservation. Notes: The significant difference was based on the 0.05 level. A: RBOHJ; B: SODA; C: CAT1; D: APX3; E: DHAR2; F: GSTU8; G: GPX6; H: GSH2. LN: pollen thawed at room temperature after cryopreservation; SNP- $0.8 \mathrm{mM}$ : pollen supplemented with $0.8 \mathrm{mM}$ SNP after cryopreservation; CPTIO- 0.8 $\mathrm{mM}$ : pollen supplemented with $0.8 \mathrm{mM}$ cPTIO after cryopreservation.

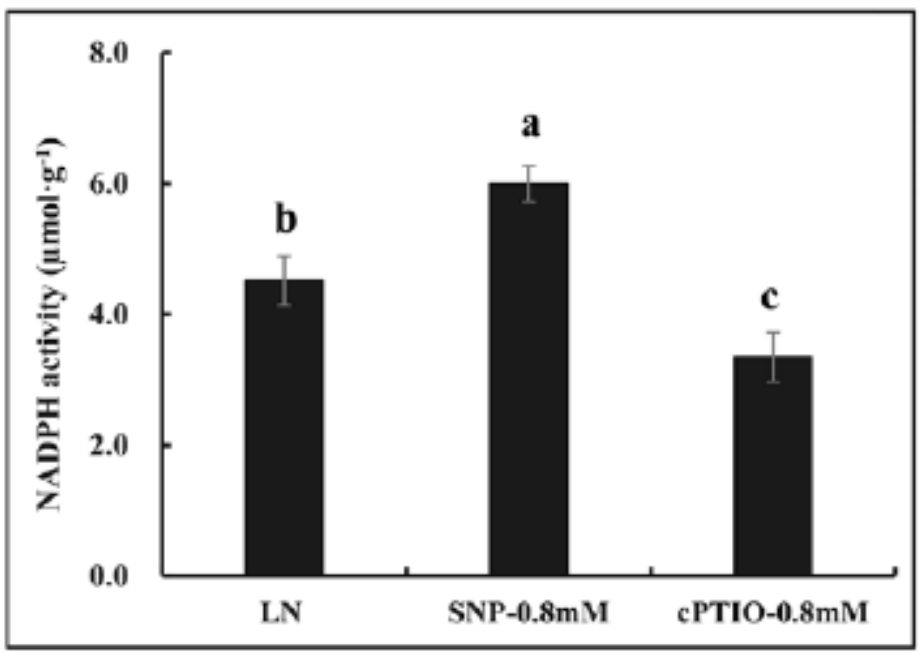

Figure 8

Changes in ROS production (NADPH oxidase) in P. lactiflora pollen with and without exogenous NO regulator treatments after cryopreservation. Notes: The significant difference was based on the 0.05 level. $\mathrm{LN}$ : pollen thawed at room temperature after cryopreservation; SNP- $0.8 \mathrm{mM}$ : pollen supplemented with $0.8 \mathrm{mM}$ SNP after cryopreservation; CPTIO- $0.8 \mathrm{mM}$ : pollen supplemented with $0.8 \mathrm{mM}$ CPTIO after cryopreservation. 

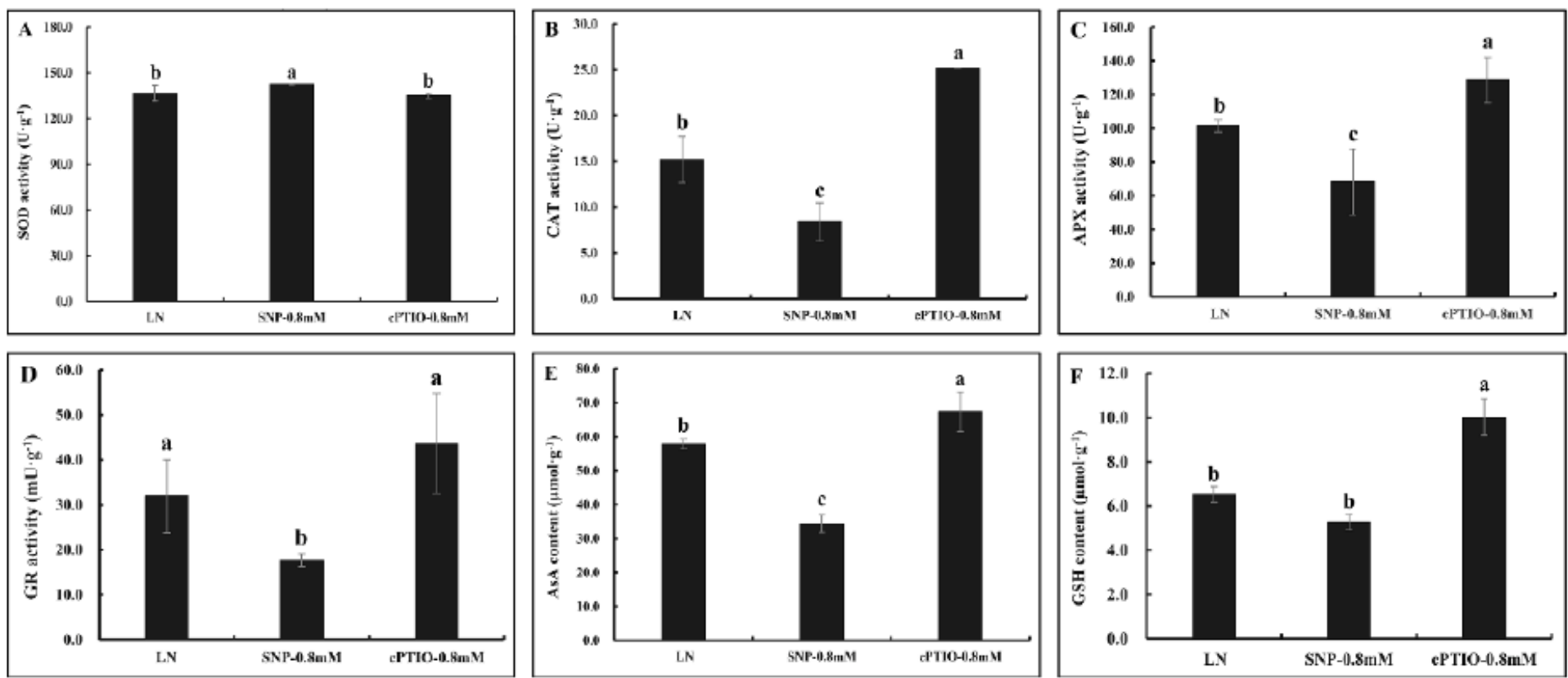

Figure 9

Changes in ROS scavenger in P. lactiflora pollen with and without exogenous NO regulator treatments after cryopreservation. Notes: The significant difference was based on the 0.05 level. A: SOD; B: CAT; C: APX; D: GR; E: AsA; F: GSH. LN: pollen thawed at room temperature after cryopreservation; SNP- 0.8 mM: pollen supplemented with $0.8 \mathrm{mM}$ SNP after cryopreservation; CPTIO- $0.8 \mathrm{mM}$ : pollen supplemented with $0.8 \mathrm{mM}$ cPTIO after cryopreservation.

\section{Supplementary Files}

This is a list of supplementary files associated with this preprint. Click to download.

- Supplemental.docx 